\title{
LUT
}

University

\section{In search of paradox management capability in supplier-customer co-development}

Oinonen Minna, Ritala Paavo, Jalkala Anne, Blomqvist Kirsimarja

This is a Final draft version of a publication

published by Elsevier

in Industrial Marketing Management

DOI: $10.1016 / j$. indmarman.2017.09.021

Copyright of the original publication: (c) Elsevier 2017

Please cite the publication as follows:

Oinonen, M., Ritala, P., Jalkala, A., Blomqvist, K. (2018). In search of paradox management capability in supplier-customer co-development. Industrial Marketing Management, Volume 74, pp. 102-114. DOI: 10.1016/j.indmarman.2017.09.021 


\title{
In search of paradox management capability in supplier-customer co-development
}

\author{
Minna Oinonen \\ School of Business and Management \\ Lappeenranta University of Technology, Finland \\ email: minna.p.oinonen@gmail.com \\ Paavo Ritala* \\ School of Business and Management \\ Lappeenranta University of Technology \\ PO BOX 20, FI-53851, Lappeenranta, Finland \\ email: ritala@lut.fi \\ tel: +358408335852 \\ *Corresponding author \\ Anne Jalkala \\ School of Business and Management \\ Lappeenranta University of Technology, Finland \\ email: anne.jalkala@gmail.com \\ Kirsimarja Blomqvist \\ School of Business and Management \\ Lappeenranta University of Technology, Finland \\ email: kirsimarja.blomqvist@lut.fi
}

\begin{abstract}
Companies increasingly involve their customers in development and innovation activities (i.e. codevelopment). This happens particularly in business-to-business markets, where customers provide the requisite knowledge for the development of complex product and service systems that help to solve customers' problems. Existing literature indicates that co-development involves inherent challenges, contradictions and tensions in the relationship between suppliers and their customers. Many of these take a form of paradox - a persistent contradiction between different alternatives in the co-development context. However, suppliers' capability to manage such paradoxes remains poorly understood. To address this gap, the framework proposed here elucidates paradox management capability in terms of two key dimensions - polarizing and juxtaposing — that occur in temporal and spatial contexts. Polarizing means focusing on one side of the paradox; juxtaposing addresses both sides simultaneously. We empirically analyze three codevelopment paradoxes related to 1) contractual and relational governance, 2) knowledge sharing and protection and 3) customer-specific and general development goals, and suggest specific management approaches that help solve these paradoxes via polarizing and juxtaposing. The results provide theoretical and practical insights for managing paradoxes that occur in codevelopment.
\end{abstract}

Keywords: Co-development; Business-to-business; Management; Paradox; Contradiction; Dynamic capability 


\section{Introduction}

Innovation in business-to-business (B2B) markets increasingly entails co-development processes involving suppliers and their customers in the development of products and services. Firms engage customers at various stages of the innovation process, such as defining the requirements and desired outcomes for the development of products and services (Johnston \& Chandler, 2012). This increasing collaboration during development reflects a shift to more complex product systems and customized solutions (Noordhoff et al., 2011; Tuli et al., 2007; Ulaga \& Reinartz, 2011). However, such relationships are not simple or straightforward, and the literature suggests that codevelopment with customers is a double-edged sword that has positive and negative effects (Peled \& Dvir, 2012). Negative effects of co-development include possible delays in the development process (Fang, 2008), as well as decreased innovativeness and the possibility of "me-too" products (Carbonell et al., 2012; Fang, 2008; Ulwick, 2002). There is also a risk that ideas from close customers will lead only to incremental innovation (e.g., Bonner \& Walker, 2004). In addition to these potential negative effects, co-development may complicate the development process itself, because of the challenges of establishing trusted partnerships, agreeing on common goals and engaging customers (Nambisan, 2002; Nicolajsen \& Scupola, 2011). We contend here that these challenges are deeply rooted in the basic principles of co-development relationships, and that it is important to understand their emergence and how they can be managed.

As previous studies have focused on identifying the possible difficulties and negative effects of customer involvement (Campbell \& Cooper, 1999; Carbonell et al., 2012; Feng et al., 2012), methods of coping with these challenges remain poorly understood. To address this gap, the present study builds on the literature of paradox and paradox management (Poole \& Van de Ven, 1989; Smith \& Lewis, 2011; Smith, 2014). In general, paradoxes can be said to refer to "contradictory yet interrelated elements that exist simultaneously and persist over time" (Smith \& Lewis, 2011, p. 382). Managing paradoxes does not mean completely eliminating the tension between such contradictory elements but rather means finding creative ways of dealing with different elements at the same time (Andriopoulos \& Lewis, 2009; Birkinshaw et al., 2016; Gaim \& Wåhlin, 2016). In the context of co-development, customer-supplier relations involve several contradictory elements that can be considered paradoxes, and these can and must be actively managed. A closer examination of paradox allows us to move from generic understanding of "challenges" (e.g., Nicolajsen \& Scupola, 2011) toward more focused analysis of the contradictory elements inherent in these relationships. To this end, our study addresses two research questions: 1) What paradoxes can be identified in supplier-customer co-development in business-to-business markets? 2) How are paradox management capabilities applied in supplier-customer codevelopment relationships?

For present purposes, supplier-customer co-development is taken to refer to any situation in which a supplier involves its customer(s) in the development of new products or services (Coviello \& Joseph, 2012; Fang, 2008; Fang et al., 2015). Adopting the perspective of a supplier seeking to develop and commercialize a new product or service for industrial markets, our study focuses on paradoxes faced by the supplier during the co-development process. To address the research questions, we build on three streams of literature. First, we briefly review the existing codevelopment literature on the contradictions inherent in such relationships as key sources of paradox. Second, drawing on the paradox management literature (e.g., Poole \& Van de Ven, 1989; Smith \& Lewis, 2011; Smith, 2014), we examine the available approaches for managing paradoxes 
at company level. These include polarizing (focusing on a single element of the paradox) and juxtaposing (addressing both elements of the paradox at the same time). Finally, building on the dynamic capabilities view (e.g., Di Stefano et al., 2014; Helfat \& Peteraf, 2015; Teece, 2007, 2014), we propose a framework for paradox management capability, and define them as strategic routines that facilitate allocation of resources for organizing the simultaneous and persisting contradictory elements in inter-organizational relationships.

To identify paradoxes and associated management approaches, we analyzed a large qualitative dataset, based on interviews with 48 people in 22 organizations and relevant secondary material. Following a pilot study, we examined three paradoxes related to governance, knowledge sharing and development goals and found evidence of different management approaches based on polarizing and juxtaposing. The findings contribute to the literature in several ways. First, we augment the literature on co-development with customers (e.g., Blazevic \& Lievens, 2008; Coviello \& Joseph, 2012; Fang, 2008; Fang et al., 2015) by identifying the key sources of paradox in this context and suggesting how firms can manage these. Second, we contribute to the marketing capabilities literature (e.g., Day, 1994; Hooley et al., 2005; Zander \& Zander, 2005) from a novel paradox management perspective (Poole \& Van de Ven, 1989; Smith \& Lewis, 2011). Finally, we extend the dynamic capabilities literature by examining paradox management as a capability to deliberately organize routines and resources to manage contradictory elements in a codevelopment context. In so doing, our insights complement an emerging stream of research on relationship and network management capabilities, which is of relevance in facilitating suppliercustomer relationship management in different phases and contexts (Forkmann et al., 2016; Mitrega et al., 2012). In particular, this literature has already established that managing conflicts and even dissolving relationships is a key feature of customer relationship management (Mitrega et al., 2012; Möller \& Halinen, 1999; Möller, 2006, Ritter \& Geersbro, 2011). We add depth to this discussion by treating paradoxes in customer co-development as contradictions that are not merely conflicts to be solved, but persistent contradictions to be managed in different ways.

The paper is organized as follows. In the next section, we discuss the nature of supplier-customer co-development and the study's theoretical foundation. After describing the methodology, we present our findings, explaining each identified paradox and approaches for their management. The paper ends with implications and conclusions.

\section{Theoretical background}

\subsection{Co-development as a relational context}

In general, to improve innovation outcomes, companies seek partners with complementary resources and capabilities (Aarikka-Stenroos et al., 2014; Corsaro et al., 2012). In B2B relationships, the complementary partner is often the customer itself, as co-development helps to identify and resolve that customer's specific problem or need. In fact, Stanko and Bonner (2013) have shown that a firm's competence in understanding customer needs improves innovativeness. Here, we focus on supplier-customer co-development, in which the customer participates in the supplier's new product or service development process (Fang et al., 2015) in order to develop new products and services that better match the customer's needs (Luzzini et al., 2015). From the supplier's perspective, the aim is to combine resources to create new products and services that the supplier could not develop alone (Fang et al., 2008). This alters the supplier-customer relationship from the traditional bidding process to a collaboration, in which the customer seeks a 
solution to a particular problem and the supplier develops new products and services to create new sales. This is particularly the case when firms co-develop knowledge-based or technologyintensive products and services (Aarikka-Stenroos \& Jaakkola, 2012; Ritala et al., 2013). The present study looks at co-development between supplier and customer(s) from the supplier's perspective in order to understand how such relationships can be managed.

While co-development of products and services may help to meet customers' needs, the literature also shows that co-development is challenging and may have several negative implications. For example, when process interdependency is high, customers as co-developers may lengthen the process; when customers' downstream connectivity is high, the product's innovativeness may suffer if customers are the main information source (Fang, 2008). In addition, involving lead users in service development has been found to have a negative effect on market share and sales growth (Carbonell et al., 2012). Collaboration with close customers is also suggested to improve innovation outcomes, but to decrease supplier innovativeness (Bonner \& Walker, 2004).

In addition to these potentially negative effects to innovation outcomes, the relationship itself may be a source of potentially negative tensions that require management attention. The B2B literature provides a well developed understanding of supplier-customer interaction in the innovation context (e.g., Aarikka-Stenroos \& Jaakkola, 2012; Blazevic \& Lievens, 2008; Johnsen, 2009; Luzzini et al., 2015), and recent studies have examined the tensions between different business actors in collaboration and competition or in collective and individual value creation (e.g., Fernandez et al., 2014; Tidström, 2014). Furthermore, co-development research has acknowledged major challenges arising in innovation collaboration between suppliers and customers (Nicolajsen \& Scupola, 2011; Smets et al., 2013; Yan \& Dooley, 2014). We argue here that relationships in this co-development context include tensions that are deeply rooted in the collaborative process itself and are common to almost all co-development processes. Managing these tensions is critical for successful co-development, and there is evidence that goal congruence, complementary capabilities and coordination of development activities can improve the quality of the codevelopment process (Corsaro et al., 2012; Yan \& Dooley, 2014). Tensions arise from specific features of supplier-customer interaction and the innovation-related goals of co-development, at worst undermining the relationship itself. In particular, we argue that these tensions often take the form of a "paradox", in that they involve simultaneously contradictory elements that persist over time (Smith \& Lewis, 2011). Building on this view, we examine the most pressing contradictory elements inherent in co-development relationships.

\subsection{Paradox in supplier-customer co-development}

The idea of paradox has been identified as a useful concept in building management and organization theories (Poole \& Van de Ven, 1989) and has more recently been used to construct theoretical frameworks to explain how firms manage contradictory elements in various settings (Lewis, 2000; Smith, 2014; Smith \& Tushman, 2005). A paradox differs from a dilemma; in the latter, alternative elements offer distinct advantages and disadvantages, allowing for choice between them (McGrath, 1982; Smith \& Lewis, 2011). In a paradox, however, the contradictory elements are simultaneously present and persist over time, requiring more careful and subtle addressing of alternatives (Smith \& Lewis, 2011; Birkinshaw et al., 2016). In the present study, paradox provides the theoretical foundation for examining the capabilities needed to manage relational contradictions in supplier-customer co-development. We believe this approach is 
particularly useful in the co-development context, where such contradictions require managerial discrimination and input.

Examples of paradoxes in this context include striking a balance between collaboration and competition (Bengtsson \& Kock, 2000; Gnyawali et al., 2016), exploring innovations and exploiting existing approaches (Andriopoulos \& Lewis, 2009; Knight \& Harvey, 2015) and balancing control and flexibility (Lewis, 2000). An increasing number of studies have suggested that pursuing competing demands simultaneously is advantageous for organizations in dynamic environments (e.g., Gaim \& Wåhlin, 2016; Lewis \& Smith, 2014; Smith \& Tushman, 2005). Similarly, Forkmann et al. (2016) adopted the customer perspective in supplier-customer relationships to identify status quo and dynamic optimization strategies as distinct supplier relationship management capabilities, requiring a balance between efficiency and flexibility. Given that co-development relationships involve suppliers and customers in an intensive relational exchange (Yan \& Dooley, 2014), these relationships might be expected to involve elements that commonly exist simultaneously and must therefore be managed as paradoxes. The next section discusses the main sources of these paradoxes.

\subsection{Key sources of paradox in co-development relationships}

There are several reasons for the emergence of paradox in co-development relationships. Here, we briefly review the relevant literature from three perspectives: 1) the value creation process, 2 ) knowledge-related issues and 3) opportunism potential and threats. These viewpoints encompass the logic of the relationship process itself, the key resources involved (i.e., knowledge) and potentially harmful activities on the part of the actors involved.

First, supplier and customer engage in co-development to create value that is mutually beneficial in terms of new or improved products or services. However, even if this is beneficial to suppliers and customers in general (e.g., Aarikka-Stenroos \& Jaakkola, 2012; Fang et al., 2015; Luzzini et al., 2015), the goals of buyers and suppliers are not usually identical, and contradictions may arise. In particular, the co-development goals of customers and suppliers may be quite different, resulting in potentially conflicting goals and collaborative tensions (Corsaro et al., 2012). In one common scenario, both actors are engaged in co-development, but the supplier seeks a new product that it can sell to multiple customers while the customer is trying to innovate a specific solution. This creates a contradiction between serving the customer's unique needs (so building the customer relationship) and satisfying a wider market to improve profitability (Nijssen et al., 2012).

Second, suppliers and customers share knowledge in co-development to create joint value. This knowledge sharing is a prerequisite for collaboration, and the basic idea of customer involvement is that the supplier shares knowledge about the development process to gain access to the customer's knowledge (Hobday, 2000; Lilien et al., 2002). However, knowledge sharing is a delicate process that also involves protection and self-regulation (see e.g., Järvenpää \& Majchrzak, 2016; Olander et al., 2010) and entails a risk of losing proprietary, business-critical knowledge. That risk is likely to increase when the customer is knowledgeable, but as such customers provide better input to the development process, suppliers must protect the knowledge they share (Noordhoff et al., 2011). There is evidence that leakage of business-critical knowledge may undermine the positive innovation effects of external knowledge sharing from the perspective of the focal firm (Ritala et al., 2015). However, mutually and individually beneficial co-development 
goals cannot be achieved without sharing and integrating knowledge, creating a persistent contradiction between knowledge sharing and protection in this context.

Third, as co-development partners have partially divergent goal structures, there are likely to be concerns about potential opportunism. Traditionally, opportunism in buyer-supplier relationships has been discussed in terms of transaction cost analysis (Coase, 1937), where opportunism means that a partner acts in its own self-interest against joint value creation, which negatively impacts performance in exchange relationships (Noordhoff et al., 2011; Rindfleisch \& Heide, 1997). However, self-interest also ensures that each actor's goals are taken into account during development. For example, Davis and Eisenhardt (2011) noted that each actor guides the development process toward their own interests, which helps to ensure a broad search for new directions and insights. As previously argued, any co-development relationship involves partially misaligned goals, with the potential for actors to act opportunistically. Given the potential for harm to collaboration, companies use specific governance mechanisms to protect themselves against opportunistic behavior, and the literature has identified contradictory elements in the governance of such relationships (see e.g., Blomqvist et al., 2005). Thus, governance is critical for codevelopment, as appropriate governance processes reduce the transaction costs related to codevelopment (Tracey et al., 2014). This involves formal and contractual governance that relies on control and legal enforcement, as well as relational governance that relies on trusting relationships. It has been suggested that these types of governance include a set of mechanisms that operate on partially contradictory principles but still exist simultaneously; for instance, explicit contracts versus reliance on relational aspects (e.g., Blomqvist et al., 2005; Olander et al., 2010).

\subsection{Paradox management capability in co-development}

To better understand suppliers' capabilities in the context of our study, we develop here a general analytical framework to examine paradox management capability and its key constituents. First, we begin by defining how the paradox management capability maps into the broader dynamic capabilities framework, since this literature involves an on-going discussion over multiple conceptual (see e.g. Di Stefano et al., 2014) as well as empirical applications (Laaksonen \& Peltoniemi, 2016). In this study, we follow the view that dynamic capabilities are bundles of organizational routines that inform managerial judgment in organizing operational resources and capabilities (Eisenhardt \& Martin, 2000; Helfat \& Peteraf, 2015; Teece, 2007, 2014; Winter, 2003). This follows the formulation of the nature of dynamic capabilities based on its constituent elements, rather than latent action (for discussion, see Di Stefano et al., 2014). In particular, we follow the view of Eisenhardt \& Martin (2000, p. 1107) in viewing dynamic capabilities as firm's strategic routines, typically orchestrated by managerial agency (e.g. Teece, 2014), that help to achieve new resource configurations under organizational change demands. This view aligns well with the context of the current study, as it has been suggested that paradox management requires a dynamic decision-making model, in which different management approaches and solutions are deployed over time (Smith, 2014; Smith \& Tushman, 2005). At best, the tensions and contradictions that constitute a paradox can yield positive results if properly managed (Gaim \& Wåhlin, 2016; Lewis, 2000).

Based on the above foundations and in the context of our study, we define paradox management capabilities as strategic routines that facilitate allocation of resources for organizing the simultaneous and persisting contradictory elements in inter-organizational relationships. This 
conceptualization positions paradox management capability as a specific type of dynamic capability that is expected to be useful in the co-development context, in which contradictory relational elements frequently exist and must be managed over time according to firm's strategic objectives for co-development.

Second, after elaborating the nature of paradox management capability, we move to discuss its key constituent elements. While dilemmas can be solved by weighing pros and cons, paradox management is more complicated. Existing studies of paradox management have identified a number of relevant processes and coping mechanisms. Generic approaches include accepting paradoxes as such, choosing between contradictory elements or dealing with them at the same time (Poole \& Van de Ven, 1989; Smith, 2014). In the current study, in conceptualizing paradox management capability, we follow a dynamic capability-based logic (e.g., Helfat \& Peteraf, 2015; Teece, 2007, 2014), focusing on deliberate managerial judgments that actively address contradictory elements. This excludes pure (and passive) "acceptance" of a paradox, which would amount to not dealing with the paradox at all. Thus, we focus on the two active managerial approaches for dealing with paradoxes that have been characterized as polarizing and juxtaposing. Polarizing simplifies the paradox as an either/or distinction before focusing on one or other pole (Lewis, 2000). Juxtaposing accommodates both poles of the paradox, requiring synthesis of the two contradictory elements (Smith \& Lewis, 2011; Smith, 2014). For present purposes, we consider these two to be the core constituents of paradox management capability.

Furthermore, in paradox literature, two contexts are generally recognized within which paradoxes are encountered and resolved: the temporal and the spatial (Poole and Van de Ven, 1989). Temporal separation involves focusing on one issue at a time before switching to another issue. The logic of temporal separation is to ease the tension of contradicting organizational issues by treating them as a sequence of events, avoiding their direct overlap at a particular moment of time (Poole \& Van de Ven, 1989; Smith \& Lewis, 2011). For example, Adler et al. (1999) demonstrated how Toyota was able to deal with the competing demands for flexibility and efficiency by separating routine and nonroutine tasks in time and switching employees sequentially between them. In an inter-organizational context, Gnyawali et al. (2016) discussed how firms can deal with the tension between simultaneous competitive and collaborative demands by temporally separating them. Spatial separation refers to allocating the management of contradictory elements to different organizational domains. As organizational domains we refer to any physical or social locus (Poole \& Van de Ven, 1989), involving spatially distinct domains of organizational action, such as functions, departments, units or project groups (Andriopoulos \& Lewis, 1999; Cantù et al., 2012). The logic of spatial separation is to ease the organizing tensions between contradictory elements by allowing individuals within a certain domain to focus on one set of issues without having to address the other pole of the paradox. For instance, Adler et al. (1999) demonstrated the periodic conflict between efficiency and flexibility in relation to automotive model changeovers, and how this paradox was managed by assigning routine and non-routine tasks to different sub-units (i.e., organizational domains) specializing in those tasks. In an inter-organizational context, Fernandez et al. (2014) demonstrated how partnering firms have eased the paradox of coopetition (collaboration and competition) by spatially separating contradictory elements. In particular, their case from the telecommunications satellite manufacturing industry showed how collaboration between partners was outsourced to a third actor (i.e., a separate organizational domain), enabling the manufacturers to focus on competition. 
Based on the insights of polarizing and juxtaposing approaches to paradoxes, as well as temporal and spatial contexts, we suggest the following conceptual framework (Figure 1) as the initial basis for analysis in the empirical part of the study.

Polarizing

Juxtaposing

\begin{tabular}{|c|c|c|}
\hline $\begin{array}{r}\text { Temporal } \\
\text { context }\end{array}$ & $\begin{array}{l}\text { Focusing on one pole of the } \\
\text { paradox at one time, and } \\
\text { shifting focus over time }\end{array}$ & $\begin{array}{l}\text { Addressing both poles of the } \\
\text { paradox at the same time }\end{array}$ \\
\hline $\begin{array}{l}\text { Spatial } \\
\text { context }\end{array}$ & $\begin{array}{l}\text { Focusing on one pole of the } \\
\text { paradox at one domain, while } \\
\text { allocating focus on other pole } \\
\text { at another domain }\end{array}$ & $\begin{array}{l}\text { Addressing both poles of the } \\
\text { paradox in the same function }\end{array}$ \\
\hline
\end{tabular}

Figure 1. Conceptual framework for paradox management capability

Figure 1 illustrates the overall repertoire of approaches for organizing paradoxes across temporal and spatial contexts. On the left are processes that make clearly polarizing choices for managing paradoxes by means of temporal or spatial separation. These entail strategic decisions in which the contradictory elements of the paradox are identified and organizational resources and processes are allocated to deal separately with these elements over time, as in the different phases of codevelopment projects (e.g., Olander et al., 2010) or by employing resources from different organizational domains, such as functions or teams (e.g., Cantù et al., 2012). On the right are approaches that juxtapose both poles of the paradox at the same time and in the same domain. The more approaches shift toward juxtaposing, the more accommodating and integrative they become. It has recently been suggested that managing paradoxes simultaneously by juxtaposing can be advantageous, as for instance when the synthesis draws on contradictory elements for creative purposes (Gaim \& Wåhlin, 2016). Overall, we expect paradox management capability to assist suppliers in managing co-development relationships by dealing effectively with paradoxes and making informed choices about whether, when and where to adopt approaches that rely on polarizing or juxtaposing.

\section{Methodology}

\subsection{Research design}

The aim of the present study was to address the following research questions: 1) What paradoxes can be identified in supplier-customer co-development in business-to-business markets? 2) How 
are paradox management capabilities applied in supplier-customer co-development relationships? To answer these questions, we selected qualitative methods, as they support holistic understanding and theory building, suited for little understood and studied topics (Patton, 2015). Using systematic combining and abductive logic, the conceptual framework and data collection and analysis evolved in successive engagements with theory and the empirical material (Dubois \& Gadde, 2002; Tavory \& Timmermans, 2014).

The research process involved two phases: a pilot study of ten co-development processes and the main study, involving interviews with 24 experts in co-development. The initial purpose of the pilot study was to study co-development processes, but as the study proceeded, management paradoxes began to emerge from the data. The role of the pilot study, then, was to identify the paradoxes, while the main study sought to validate those paradoxes and to identify relevant management approaches. Overall, the data were collected in 48 interviews in 22 organizations and were supported by secondary data, such as companies' annual reports and web pages, codevelopment process descriptions and memos from customer meetings. Most of the interviews were conducted face-to-face, with the exception of five that were conducted by phone. The interviews lasted between 26 and $146 \mathrm{~min}$ ( $75 \mathrm{~min}$ on average), and all but one was tape-recorded and transcribed verbatim, yielding 590 single-spaced pages in total. The overall research design is summarized in Figure 2.

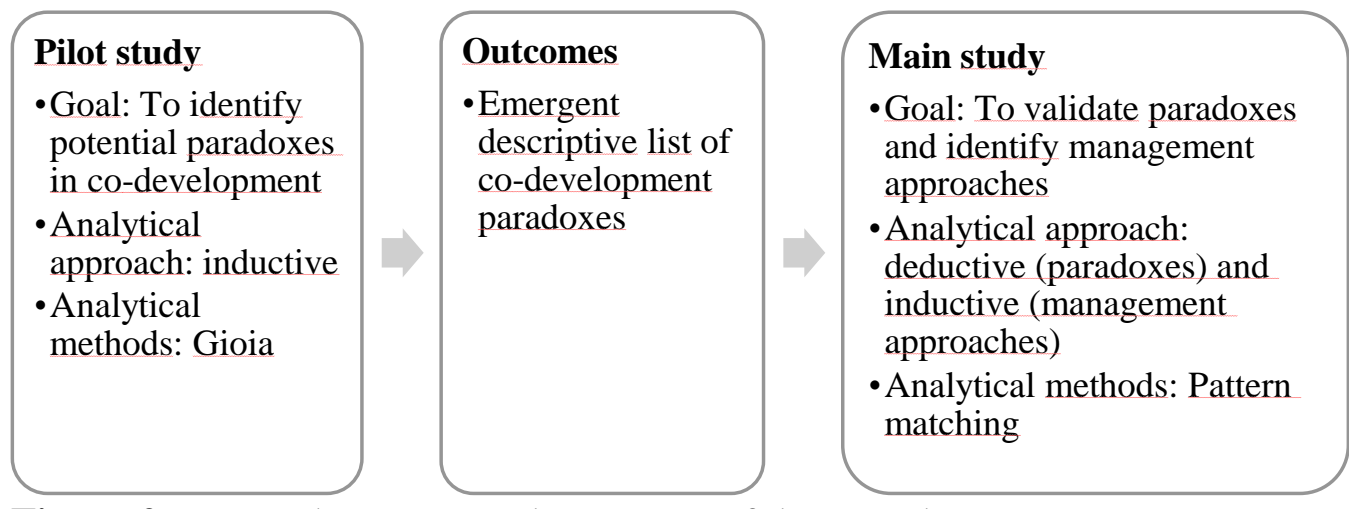

Outcomes
- Affirmation of key
paradoxes in co-
development
- Management
approaches
indicating the
application of
paradox management
capabilities across
studied organizations

Figure 2. Research process and outcomes of the two phases

\subsection{Pilot study}

In the pilot study, we analyzed ten supplier-customer co-development processes at two global companies: a mining technology provider and an industrial measurement system provider. We selected these suppliers because 1) they had experience of collaborating with different types of customers, involving multiple co-development processes; 2) they offered the requisite variety for the analysis of successful co-development and 3) they provided good access to co-development processes. The mining technology provider had years of experience in co-developing new products and services with customers and had established strategic co-development partnerships with both existing and new customers. The selection of cases relied on snowball sampling (Biernacki \& Waldorf, 1981), which began by contacting the firm's automation director, as the development of process automation requires close collaboration with customers. The cases included the development of different analyzers for measuring the metal enrichment process, as well as reporting and education tools. The second supplier (industrial measurement system provider) was developing company-wide practices and guidelines for co-development. Their head of offering 
was asked to provide examples of different co-development cases. The development projects of two different probes were selected among six potential cases as they provided better access to data and these cases included positive and negative examples of co-development processes.

Of the ten selected development processes, six resulted in a commercialized product. These included a monitoring system for mining process, two different kinds of mining process analyzers, a mixer for mining sludge, a reporting tool for the enrichment process and a probe for incubators. The processes relating to the development of an education tool for the mining process and another probe for industrial measurement were prolonged and had not achieved commercialization. Development of another analyzer and analyzer software for the mining industry were terminated before yielding any final product because of their lack of commercial potential.

The primary sample for the pilot study comprised 22 interviewees at six organizations: 12 managers at the two suppliers, eight representatives of three customers and two university researchers who were involved as expert partners in two of the processes (see Table 1). The analysis was supported by secondary material from the development process, such as product brochures, memos from customer meetings and process descriptions.

The analysis approach was inductive as the purpose of the study was not initially to identify paradoxes. Thus, no coding scheme or existing framework was imposed but instead the findings emerged from the data inductively after open coding. The coding followed the Gioia method which consist of three coding phases (Gioia et al., 2013). In the first phase, we open coded each interview in vivo, using the informants' own words. To allow themes to emerge from the data, we focused on finding potential paradoxes and management approaches, carefully coding the tensions and challenges mentioned by respondents and responses to those challenges. Emerging themes included contradictory goals, accessing data/losing proprietary knowledge, resource allocation, value appropriation, timeline alignment, partner selection, agreeing on contracts and process management. In the second phase, we assessed whether the identified tension was a paradox with two opposing poles or a dilemma that could be solved by weighing pros and cons. On that basis, some identified challenges, such as partner selection, were excluded from the analysis which focused on paradoxes and their management. Potential paradoxes were formulated by grouping similar codes together and assigning more abstract labels to the codes. In the third phase, we focused on relationships between the codes and assembled our findings from the pilot study. At this point, we also clarified the paradoxes identified and created definitions for them on the basis of the data. 
Table 1. Pilot study interviews

\begin{tabular}{|c|c|c|c|c|c|}
\hline $\begin{array}{l}\text { Co- } \\
\text { development } \\
\text { process } \\
\text { outcomes }\end{array}$ & $\begin{array}{l}\text { No. of } \\
\text { interviewed } \\
\text { persons }\end{array}$ & $\begin{array}{l}\text { Interviewed } \\
\text { persons / mining } \\
\text { technology } \\
\text { provider }\end{array}$ & $\begin{array}{l}\text { Interviewed } \\
\text { persons / } \\
\text { industrial } \\
\text { measurement } \\
\text { system provider } \\
\end{array}$ & $\begin{array}{l}\text { Interviewed persons / } \\
\text { customers }\end{array}$ & $\begin{array}{l}\text { Interviewed } \\
\text { persons / } \\
\text { research } \\
\text { institution }\end{array}$ \\
\hline $\begin{array}{l}\text { 1: Education } \\
\text { tool for } \\
\text { mining } \\
\text { process }\end{array}$ & 3 & $\begin{array}{l}\text { Development } \\
\text { Manager }\end{array}$ & & $\begin{array}{l}\text { Customer A: Mill } \\
\text { Superintendent }\end{array}$ & Researcher 1 \\
\hline $\begin{array}{l}\text { 2: Monitoring } \\
\text { system for } \\
\text { mining } \\
\text { process }\end{array}$ & 3 & $\begin{array}{l}R \& D \text { Vice } \\
\text { President }\end{array}$ & & $\begin{array}{l}\text { Customer A: Manager } \\
\text { of Processing; } \\
\text { Safety, Health and } \\
\text { Environmental } \\
\text { Manager }\end{array}$ & \\
\hline $\begin{array}{l}\text { 3: Analyzer } \\
\text { for mining } \\
\text { process }\end{array}$ & 6 & Product Manager & & $\begin{array}{l}\text { Customer B: } \\
\text { Production Foreman; } \\
\text { Operating Engineer; } \\
\text { Research Manager } \\
\text { Customer C: Senior } \\
\text { Control System } \\
\text { Engineer; IT Director }\end{array}$ & \\
\hline $\begin{array}{l}\text { 4: Analyzer } \\
\text { for mining } \\
\text { process }\end{array}$ & 2 & $\begin{array}{l}\text { Automation } \\
\text { Director }\end{array}$ & & & Researcher 2 \\
\hline $\begin{array}{l}\text { 5: Analyzer } \\
\text { for mining } \\
\text { process }\end{array}$ & 1 & $\begin{array}{l}\text { Research \& } \\
\text { Concept } \\
\text { Development } \\
\text { Manager }\end{array}$ & & & \\
\hline $\begin{array}{l}\text { 6: Reporting } \\
\text { tool for } \\
\text { mining } \\
\text { process }\end{array}$ & 1 & Sales Manager & & & \\
\hline $\begin{array}{l}\text { 7: Mixer for } \\
\text { mining sludge }\end{array}$ & 1 & $\begin{array}{l}\text { Technology } \\
\text { Director }\end{array}$ & & & \\
\hline $\begin{array}{l}\text { 8: Analyzer } \\
\text { software for } \\
\text { mining } \\
\text { process }\end{array}$ & 1 & Sales Director & & & \\
\hline $\begin{array}{l}\text { 9: Probe for } \\
\text { incubator }\end{array}$ & 4 & & $\begin{array}{l}\text { Project } \\
\text { Manager; } \\
\text { Product } \\
\text { Manager; Head } \\
\text { of Offering; } \\
\text { Development } \\
\text { Manager }\end{array}$ & & \\
\hline $\begin{array}{l}\text { 10: Probe for } \\
\text { industrial } \\
\text { measurement }\end{array}$ & $*$ & & $\begin{array}{l}* \text { Same } \\
\text { interviewees for } \\
\text { processes } 9 \text { and } \\
10\end{array}$ & & \\
\hline Total & $\begin{array}{l}22 \\
\text { interviewees }\end{array}$ & $\begin{array}{l}\text { Altogether } 6 \text { orga } \\
2 \text { providers, } 3 \text { cus }\end{array}$ & $\begin{array}{l}\text { izations: } \\
\text { omers and a resea }\end{array}$ & h institute & \\
\hline
\end{tabular}


The pilot study resulted in the identification of four paradoxes and two or three management approaches for each. The first paradox concerned contractual and relational governance; the pilot data highlighted the importance of defining goals, terms and responsibilities early on in the process while maintaining an open atmosphere that fosters trust and innovativeness. This was evident in the case of the industrial measurement system provider's selection of governance approach. For example, in the case of probe development, interviewees at the industrial measurement provider said "The customer thinks that if they sign a watertight contract, everything will go well. We do not want a contract at all because it is not beneficial for us to agree on everything while the customer does not commit to anything." However, the company commonly committed to some form of contractual governance as in another case they referred to: "We had non-disclosure agreements and some sort of letter of intent, after which we received their specifications, but we did not sign any actual contract for co-development."

The second paradox related to sharing and protecting knowledge; interviewees stressed the importance of maintaining a balance between knowledge sharing and protection of one's proprietary knowledge. As a sales director involved in the development of analyzer software stressed, "We need NDAs [non-disclosure agreements] and all that stuff." In the mining industry, there are also differences between customers that a supplier can share knowledge with and customers that share knowledge with the supplier. As a technology director put it, "In mining companies, gold miners are the most secretive. Whatever they are doing, it is always secret." Interviewees also pointed out that while sharing knowledge bears a risk, it is a prerequisite for getting access to customer data that the supplier might not otherwise have. In addition, while the multiple interviewees stressed that supplier needs to protect the proprietary knowledge, some also mentioned that it is beneficial that customer learns about potential solutions already before they are on the market.

The third paradox related to development goals, both generic and customer-specific. Interviewees in the two supplier companies emphasized that the customer often needs to solve a unique problem. On the other hand, the supplier has to serve a larger market, but creating a general solution may destroy the customer's competitive advantage as a sole implementer. For example, the representative of the research institution noted that in the development of the education tool, supplier and customer had contradictory goals: "The goals might sometimes be contradictory. For example, in this case, the customer did not get as many benefits as the supplier." The supplier's development manager also acknowledged the challenge of creating both a tailored and a general solution: "It is problematic if customer is too strongly involved as then they will develop a solution only for the single customer's need and from our perspective it should be a general solution that is also suitable for the collaboration partner's needs."

The fourth paradox concerned accelerating and delaying commercialization. Many of the interviewees observed that limited customer resources could lengthen the development process, as the customer's first priority is to keep its own operations running. This was apparent, for instance, in case 3 (development of a mining process analyzer): "This guy [the customer's senior control system engineer] did not have time for development, and the process did not proceed. It was kind of a critical phase, and I thought nothing was going to happen." The interviewees from the mining technology company also noted that the nature of the process industry presents timing challenges, 
as you might have to wait for a customer's maintenance break before installing the new technology to be tested.

\subsection{Main study}

In the main study, the analysis had two goals: to assess whether the paradoxes identified in the pilot study were also salient for multiple industries and to identify approaches for managing paradoxes, reflecting the existence (or lack) of organizational application of paradox management capabilities across the companies. Theoretical sampling was used to target the 100 largest companies in Finland (based on turnover), of which 88 conducted development activities. (Twelve companies were excluded as they were investment companies and had no customer codevelopment activities.) The focus on large companies reflected our belief that they have more systematic approaches for managing paradoxes. We made initial contact with innovation or R\&D directors or similar and asked them to forward our message to people who had been involved in co-development. Twenty companies agreed to participate in the study; of these, we excluded four that operated only in consumer markets. The final sample for the main study comprised 24 interviewees from 16 companies (one to three persons in each company; see Table 2).

Table 2: Main study interview sample

\begin{tabular}{|c|c|c|c|}
\hline Industry (based on SIC codes) & $\begin{array}{l}\text { No. of } \\
\text { companies }\end{array}$ & $\begin{array}{l}\text { No. of interviewed } \\
\text { persons }\end{array}$ & Titles of interviewed persons \\
\hline Mining & 1 & 3 & $\begin{array}{l}\text { Business Unit Director, R\&D Networks } \\
\text { Manager; R\&D Project Management Manager }\end{array}$ \\
\hline Construction & 2 & 2 & Account Director, Director \\
\hline Manufacturing & 7 & 12 & \\
\hline - $\quad$ Primary Metal Industries & 2 & 3 & $\begin{array}{l}\text { Research Manager, Product Development } \\
\text { Manager, Senior Product and Application } \\
\text { Manager }\end{array}$ \\
\hline $\begin{array}{l}\text { - Industrial and Commercial } \\
\text { Machinery and Computer } \\
\text { Equipment }\end{array}$ & 2 & 4 & $\begin{array}{l}\text { R\&D Director, Customer Insight Professional, } \\
\text { R\&D Usability Designer, Product Manager }\end{array}$ \\
\hline $\begin{array}{l}\text { - Chemicals and Allied } \\
\text { Products }\end{array}$ & 1 & 1 & Head of Development \\
\hline $\begin{array}{l}\text { - Rubber and Miscellaneous } \\
\text { Plastics Products }\end{array}$ & 1 & 2 & Development Manager, R\&D Project Manager \\
\hline $\begin{array}{l}\text { Measuring, Analyzing, and } \\
\text { Controlling Instruments; } \\
\text { Photographic, Medical and } \\
\text { Optical Goods; Watches and } \\
\text { Clocks }\end{array}$ & 1 & 2 & Director, Project Manager \\
\hline Wholesale Trade & 1 & 1 & Associate \\
\hline $\begin{array}{l}\text { Transportation \& Public } \\
\text { Utilities }\end{array}$ & 2 & 2 & $\begin{array}{l}\text { Senior Development Manager, Head of } \\
\text { Commercial Development and Business } \\
\text { Transformation }\end{array}$ \\
\hline Services & 1 & 2 & Customer Account Director (2 people) \\
\hline Not specified & 2 & 2 & Head of Business Unit, Development Manager \\
\hline Total & 16 & 24 & \\
\hline
\end{tabular}


The participating companies represented multiple industries, such as mining, construction and transportation, and multiple manufacturers, such as machinery and medical companies. Respondents included innovation or $\mathrm{R} \& \mathrm{D}$ directors, customer insight experts and project managers. We relied on open-ended questions about the co-development challenges faced by the company and ways of addressing those challenges. If interviewees did not mention the four paradoxes identified in the pilot study (governance, knowledge sharing, development goals and the co-development time span), we asked how they saw the processes in which they had participated. If they pointed out any associated challenges, we asked how they managed those challenges. To support the analysis, we also reviewed the companies' web pages and annual reports to identify strategies and contractual principles and to get information on approaches that each company used to protect knowledge, such as patents.

Both deductive and inductive analytical approaches were used during the main study. The analysis focusing on validating the identified paradoxes was deductive and used pattern matching (Saunders et al., 2009) as the coding was guided by the four paradoxes identified in the pilot study and the existing literature on supplier-customer co-development. We also validated the findings in the two pilot companies by conducting two follow-up interviews with the design managers in both companies and by presenting the findings in managerial workshops in each case, but no changes were suggested at this point.

To identify the management approaches for each paradox, an inductive analytical approach was adopted. The theoretical framework for paradox management capability guided the coding, while the empirical applications and actions related to paradox management capabilities inductively emerged from the data. This approach has been used in other capability-related studies in the supplier-customer context (e.g., Ritala et al., 2013). In identifying the management approaches for different paradoxes, we followed a commonly used way to empirically study dynamic capabilities - the organizational actions (for review, see Laaksonen \& Peltoniemi, 2016). In particular, to study DCs as routines in their organizational use, we follow scholars that suggest examining the performative artefacts of routines as a way of gaining understanding of them (Feldman, 2003; Pentland \& Feldman, 2005). Thus, our analysis generated evidence of various types of management approaches, which can be perceived as performative artefacts of the paradox management capabilities in their organizational context.

The analysis showed that the previously identified paradox of accelerating and delaying commercialization was not considered relevant by informants in the main study. The interviewees did not refer to this paradox, and when asked directly about it, they said that co-development had no major effect on development process duration. As one interviewee put it, "It does not have a major effect. Of course, it depends on how much we discuss with the customer, but it [the possible delay] depends on how we organize the process." Another interviewee pointed out that while codevelopment shortens the overall process, the effect is minor for overall process time: "Of course, if we have a partner, it is more straightforward. We might win some [time], but it does not matter because we are talking about a month or two in very long projects." The next section discusses the findings of the main study. 


\section{Findings}

The analysis revealed that when co-developing with customers, the companies managed three paradoxes: 1) contractual and relational governance, 2) sharing and protecting knowledge and 3) generic and customer-specific development goals. Based on our analysis of the different paradox management approaches for temporal and spatial dimensions, the companies were found to approach paradoxes in four specific ways: by polarizing one pole of the paradox consistently; by switching the polarizing approach over time or spatial domain; or by juxtaposing both poles simultaneously. Table 3 summarizes the main findings of the study; each paradox and associated management approaches are discussed in more detail below. 
Table 3. Management approaches for co-development paradoxes

\begin{tabular}{|c|c|c|c|c|}
\hline & Full polarizing & Polarizing over time & $\begin{array}{l}\text { Polarizing over spatial } \\
\text { domain }\end{array}$ & Juxtaposing \\
\hline Governance & $\begin{array}{l}\text { Contractual governance: Focus } \\
\text { on contractual governance in all } \\
\text { phases of the process and } \\
\text { relationship/in all } \\
\text { organizational domains (e.g., } \\
\text { co-development only when } \\
\text { contracts have been signed) } \\
\text { Relational governance: Focus } \\
\text { on relational governance in all } \\
\text { phases of the process and } \\
\text { relationship/in all } \\
\text { organizational domains (e.g., } \\
\text { co-development with customers } \\
\text { who can be trusted; avoidance } \\
\text { of contracting; emphasis on } \\
\text { openness) }\end{array}$ & $\begin{array}{l}\text { Creating contracts in the early } \\
\text { stages of the } \\
\text { process/relationship and using } \\
\text { relational governance in the } \\
\text { later stages of the } \\
\text { process/relationship (e.g., } \\
\text { making an effort to negotiate } \\
\text { tight contracts at the beginning } \\
\text { of the collaboration but } \\
\text { relying on discussion later on } \\
\text { in the process) }\end{array}$ & $\begin{array}{l}\text { Employees from one domain } \\
\text { focus on contractual } \\
\text { governance while other } \\
\text { domains focus on relational } \\
\text { governance (e.g., the legal } \\
\text { department negotiates } \\
\text { contracts about } \\
\text { responsibilities, and the } \\
\text { development project team } \\
\text { builds personal relationships } \\
\text { with collaboration partners) }\end{array}$ & $\begin{array}{l}\text { Building long-term strategic } \\
\text { partnerships based on } \\
\text { contractual and relational } \\
\text { governance (e.g., long-term } \\
\text { collaboration contract and } \\
\text { collaborative norms for } \\
\text { collaborating with strategic } \\
\text { customers that also benefit } \\
\text { from the collaboration) }\end{array}$ \\
\hline Knowledge & $\begin{array}{l}\text { Knowledge protection: } \\
\text { Focus on knowledge protection } \\
\text { in all phases of the process and } \\
\text { relationship/in all } \\
\text { organizational domains (e.g., } \\
\text { relying on non-disclosure } \\
\text { agreements and intellectual } \\
\text { property rights and limiting } \\
\text { revealed knowledge) } \\
\text { Knowledge sharing: Focus on } \\
\text { sharing knowledge in all phases } \\
\text { of the process and } \\
\text { relationship/in all } \\
\text { organizational domains (e.g., } \\
\text { sharing knowledge freely also } \\
\text { before contracts are signed or } \\
\text { strong ties are built) }\end{array}$ & $\begin{array}{l}\text { Protecting knowledge in the } \\
\text { early phases of the process or } \\
\text { relationship and sharing } \\
\text { knowledge in the later stages } \\
\text { of the process or in long- } \\
\text { lasting relationships (e.g., } \\
\text { limiting shared knowledge } \\
\text { during the ideation phase and } \\
\text { sharing more knowledge later } \\
\text { during the development } \\
\text { phases; protecting knowledge } \\
\text { when collaborating with new } \\
\text { partners and sharing } \\
\text { knowledge freely as the } \\
\text { partnership matures) }\end{array}$ & $\begin{array}{l}\text { Employees in one domain } \\
\text { focus on knowledge sharing } \\
\text { while other domains are } \\
\text { responsible for managing } \\
\text { knowledge protection (e.g., } \\
\text { legal department/director level } \\
\text { protects knowledge, and the } \\
\text { development project team } \\
\text { shares knowledge) }\end{array}$ & $\begin{array}{l}\text { Sharing knowledge freely } \\
\text { while making sure that the } \\
\text { firm does not lose its } \\
\text { competitive edge (e.g., } \\
\text { sharing knowledge } \\
\text { continuously on new } \\
\text { products, while pushing } \\
\text { forward with development so } \\
\text { that competitors cannot catch } \\
\text { up by imitating) }\end{array}$ \\
\hline
\end{tabular}




\begin{tabular}{|c|c|c|c|c|}
\hline $\begin{array}{l}\text { Development } \\
\text { goals }\end{array}$ & $\begin{array}{l}\text { Customer-specific: Focus on } \\
\text { creating customer-specific } \\
\text { products and services in all } \\
\text { phases of the process and } \\
\text { relationship/in all } \\
\text { organizational domains (e.g., } \\
\text { creating only customized } \\
\text { offerings or tailored, exclusive } \\
\text { offerings for certain customers) } \\
\text { General: Focus on serving } \\
\text { wider market needs in all } \\
\text { phases of the process and } \\
\text { relationship/in all } \\
\text { organizational domains. } \\
\text { (e.g., declining to customize } \\
\text { any offerings) }\end{array}$ & $\begin{array}{l}\text { Creating a first version as } \\
\text { customer-specific and then } \\
\text { further developing a general } \\
\text { version (e.g., providing } \\
\text { exclusive rights for a certain } \\
\text { period of time and then } \\
\text { providing the same solution to } \\
\text { other customers) }\end{array}$ & $\begin{array}{l}\text { Employees in one domain } \\
\text { focus on creating a general } \\
\text { version while employees in } \\
\text { another domain focus on } \\
\text { creating a customer-specific } \\
\text { solution } \\
\text { (e.g., product manager focuses } \\
\text { on creating a general product } \\
\text { while development engineers } \\
\text { focus on solving a customer- } \\
\text { specific problem) }\end{array}$ & $\begin{array}{l}\text { Selecting customers who are } \\
\text { representative of markets so } \\
\text { that a solution customized to } \\
\text { the partner customer also } \\
\text { serves the wider market } \\
\text { (e.g., collaborating with two } \\
\text { customers from different } \\
\text { market segments) }\end{array}$ \\
\hline
\end{tabular}




\subsection{Contractual and relational governance}

The paradox of contractual and relational governance concerns how collaboration is managed. Our data highlighted the importance of agreeing contracts for co-development goals and responsibilities while maintaining an open atmosphere that fosters trust and innovativeness. While interviewees emphasized the importance of defining goals, terms and responsibilities in contractual form, contracts may prevent partners from looking in new directions and beyond existing ways of doing things - qualities that are important for radical innovation.

For example, interviewees at an industrial measurement system provider noted that because watertight contracts limit the scope of co-development, they aimed to create mutual understanding rather than contracting. A development manager at a manufacturing company said that they did not want to sign contracts, as they make collaboration too formal: "If you try to make it too formal and contractually binding in some way, especially in the early phases, it makes it so much more difficult because people can easily retreat from it." For that reason, some companies polarized relational governance by creating partnerships and building trust. These companies also emphasized the mutual benefits of collaboration for supplier and customer.

In contrast, another manufacturer required a signed contract with each collaborating customer. According to one interviewee, "Since we have such a large customer base, and several suppliers, we need to have pretty much the same contract terms for everyone." Another interviewee said, "We are quite insistent about that... It is like, take it or leave it." The mining technology company polarized its attention to focus on contractual governance and tended to sign contracts defining intellectual property rights before commencing collaboration with customers. A similar fully polarizing approach was adopted by a large services company. An interviewee said: "We do not talk about it until we have a contract."

A number of companies also polarized time or domain to manage the paradox of governance. For example, the larger companies all had legal departments that focused on creating contracts for codevelopment while the people directly involved in the co-development process concentrated on building good relationships - in other words, polarizing was based on separation between organizational domains. Some respondents - such as the research manager from a metal industry firm - also emphasized contractual governance at the early stages of the process: "We need to agree on the rules of the game. There is a research collaboration contract that determines tough issues such as how IPRs [Intellectual Property Rights] are dealt with, how costs are divided and so on." Relational governance, on the other hand, was used in the later stages of the process or in the case of long-standing customer relationships, indicating a temporal approach to polarizing.

With regard to juxtaposing, several companies had built strategic partnerships based both on contracts and on close relationships involving mutual trust. For instance, one manufacturing company adopted a long-term strategic partnership approach, engaging its strategic customers across different projects and flexibly combining joint projects with research institutes, pilot projects with customers and spin-offs.

\subsection{Knowledge sharing and protection}

Interviewees also highlighted the importance of maintaining a balance between knowledge sharing and protection. By sharing knowledge, the supplier gains access to customer data that they might 
not otherwise have. However, managers also emphasized that knowledge sharing entails the risk of exposing proprietary knowledge that the other actor may exploit or that may cause harm if leaked. Interviewees at companies whose competitiveness was embedded in superior products and related proprietary knowledge feared exposing knowledge of their new product when codeveloping with customers: "If we want to patent new products, we must take care that they do not leak in advance through customers." For that reason, several companies fully polarized knowledge protection by creating non-disclosure agreements, limiting shared knowledge and relying on IPRs.

In contrast, some companies perceived protection itself as problematic. They decided to polarize fully on knowledge sharing, arguing that an overemphasis on knowledge protection would risk the loss of customer-side insights. They also noted that it is problematic if a customer is unwilling to share knowledge. One interviewee discussed this issue explicitly, suggesting that if knowledge is not freely shared, there is "a huge risk that the company will become inward-looking and does not listen to what is happening out there." Companies that polarize knowledge sharing were eager to collaborate with others; indeed, several interviewees even stated that they saw knowledge sharing as proactive marketing and so aimed to demonstrate new products and services in every phase of the development process. Some suppliers using this approach were proactive in polarizing knowledge sharing with their co-development partners while not using contracts. As one interviewee put it, "I have decided to let go of all these NDAs, and it is more implicitly agreed...I will make sure that the customer's identity is not leaked."

Spatial and temporal polarizing solutions were also identified. As an approach to polarizing in different spatial domains, the legal department in some companies focused on protecting knowledge while the development team managed knowledge sharing. In another spatial solution in the co-development context itself, certain knowledge domains were deliberately separated between supplier and customer. According to one interviewee, "We have accepted the situation, that this is just how it goes. They [the customer] have a certain field that they want to keep for themselves, and we can see that they seek to restrict it [the knowledge domain] so that we do not go there in this project." Several companies also adopted a temporal approach to polarizing sharing and protection. Interviewees acknowledged the risks of sharing knowledge, and the companies polarized knowledge sharing and protection through IPRs and contracts to ensure that proprietary knowledge was protected in the early stages. However, once contracts were signed, the companies shared knowledge freely. One interviewee described the approach as follows: "When we have a patented product, we involve customers all along and start to collaboratively develop applications for the early product idea and to test the effects in different markets."

Companies that juxtapose knowledge sharing and protection have found ways of sharing knowledge to maintain their technological lead and to keep proprietary developments safe. One example was a company that shared knowledge freely but protected itself from copying by constantly developing their offerings. In many cases, juxtaposing also relied on a pragmatic approach to knowledge sharing and protection, including "being sensible about deciding what to share" and relying on "gentleman's agreements." 


\subsection{Customer-specific and general development goals}

Interviewees clearly identified the challenge of solving a customer-specific problem while addressing wider market needs. While solving a customer-specific problem motivates the customer to become engaged in co-development, the supplier needs to serve a larger market to generate revenue. As one interviewee stated, "We provide big facilities that are typically customized for each customer, but we analyze the commercial potential of the new system on a general level beyond the single customer."

Some firms have addressed this challenge by polarizing fully toward customer-specific development goals, choosing to create only customized products and services. For example, some firms create multiple versions of the same product or service using modularity while also developing exclusive offerings for customers. One maintenance service provider who operated in this way had general service offerings but always customized services to the customer's needs. In contrast, some companies focused fully on general development goals and refused to customize or provide exclusive rights. For example, the mining technology company focused on wider market needs as it needed sales volume to cover the costs of long development projects. One interviewee stated that "We usually avoid making something for one customer that might dictate that the product would be delivered just for them."

Some companies polarize customer-specific and generic development goals in terms of time or domain. For example, the industrial measurement system provider first developed a customized version for the co-development partner and only then focused on creating a version that the company could launch in the wider market. According to one interviewee, "They would have wanted exclusive rights, but we knew that their market was not large enough. So, we customized the first version for them, and only the second release was for the entire market." In some companies, certain departments focus on creating the customized version while other departments produce standard products, polarizing through different organizational units or functions. As a representative of the metal industry company explained, this decision was often based on the supplier's assessment of the feasibility of separating customer projects: "If the volume is large enough with a single customer, then we will do it, but if it is small, then we will make a serious judgment about whether to make a customized product or to offer something pre-existing."

A number of feasible juxtaposing solutions were also identified for managing the persistent contradiction between generic vs. customer-specific development goals. For instance, several manufacturers sought to collaborate with partners that represented "generic" market needs, enabling them to address customer-specific and market needs simultaneously. There was also some evidence of paradox management capability development in this regard; one interviewee noted that whereas they might in the past have "taken it too far with one or particular persons, and in the next step found it a bit different...... This has taught us that we need to take in the whole customer portfolio [in developing products]." Another company adopted the practice of always involving several customers in their co-development projects in order to form "a shared consensus" about broader market needs while still meeting the needs of the co-development partners. 


\section{Discussion and conclusions}

Supplier-customer co-development involves inherent challenges (Nambisan, 2002; Nicolajsen \& Scupola, 2011) that can be seen as persistent, strategic contradictions (Smith \& Tushman, 2005). In the present study, we have argued that supplier organizations can benefit from the capability to deal with these contradictions as paradoxes, which can be managed by making deliberate choices in temporal and spatial contexts. In a broad-based qualitative study, we analyzed three particular paradoxes in the co-development context, related to 1) contractual and relational governance, 2) knowledge sharing and protection and 3) customer-specific and general development goals. Our results demonstrate how companies can manage these paradoxes by means of fully polarizing on a particular element of the paradox, polarizing over time or organizational domain, or by juxtaposing, i.e. addressing both poles of the paradox simultaneously or in the same domains. These findings have a number of novel implications for paradox management and co-development research and practice which we will discuss next.

\subsection{Implications for research}

Our findings contribute to the literature on co-development by deepening the understanding of the sources of paradox in such relationships. Previous studies have revealed general insights into challenges in these relationships (e.g., Nambisan, 2002; Nicolajsen \& Scupola, 2011), including evidence that co-development is affected by customer type and their role in the process (Fang, 2008). However, few existing studies have focused empirically on the persisting contradictory elements in these relationships, and paradox management research suggests that this line of inquiry would improve understanding of innovation activities and processes (e.g., Andriopoulos \& Lewis, 2009; Gaim \& Wåhlin, 2016; Smith \& Tushman, 2005). Our empirical analysis of the contradictory elements that constitute paradoxes, and of related managerial responses, provides valuable insights into supplier-customer co-development (Chang \& Taylor, 2016; Coviello \& Joseph, 2012; Yan \& Dooley, 2014) and, more broadly, industrial innovation networks (Corsaro et al., 2012). Our findings also contribute to the broader paradox management literature by empirically illustrating the role of different paradox management approaches in the context of supplier-customer co-development. The framework and empirical insights showcase the broad repertoire of temporal and spatial solutions to polarizing and juxtaposing, deepening understanding of how paradoxes are managed in a relational context. This augments a literature that commonly focuses on the organizational rather than the inter-organizational level of analysis (see e.g., Birkinshaw et al., 2016; Smith, 2014). The findings also show how paradox management can be used to facilitate - or at least enable - creativity and innovativeness in actively addressing contradictory elements, as recently suggested by Gaim and Wåhlin (2016).

The present findings also provide particular insights into relationship and network management capabilities (e.g., Forkmann et al., 2016; Möller \& Halinen, 1999; Möller, 2006). This literature has previously focused on such issues as customer portfolio management in terms of building, maintaining, and dissolving customer and supplier relationships (Möller \& Halinen, 1999; Ritter \& Geersbro, 2011; Mitrega \& Pfajfar, 2015; Forkmann et al., 2016). Our study contributes to this literature in a number of ways. First, the variety of means by which customers can be leveraged as a source of innovation supports the view that customer-based assets are of great value for innovation purposes (Hooley et al., 1998). While existing research has focused on such issues as selection of the best possible customers as innovation partners (Corsaro et al., 2012), the present study addresses the management of challenges arising from relational complexity in co- 
development processes. Second, this study contributes to the literature on marketing assets and capabilities by investigating the management of co-development paradoxes from the supplier perspective. Despite extensive efforts to identify, define and categorize marketing assets and capabilities, the extant literature does not treat effective management of customers' innovation input as a potential capability. The various classifications of marketing assets and capabilities (e.g., Day, 1994; Hooley et al., 2004, 2005; Zander \& Zander, 2005) tend to overlook this type of capability, which according to our findings it is potentially of relevance for industrial suppliers. The present study views the balancing of contractual and relational governance, knowledge sharing and protection, as well as customer-specific and generic market needs, as a multidimensional paradox management capability. In so doing, we join the studies advocating the need to manage conflicts in B2B customer relationships over the course of their life cycle (e.g., Mitrega et al., 2012). We complement this line of research by particularly focusing on capabilities for managing contradictions characterized by simultaneously opposing demands and processes, which are especially likely to arise in co-development relationships (e.g., Olander et al., 2010; Cao \& Lumineau, 2015). Supported by empirical evidence, the proposed framework offers a preliminary account of the components of paradox management capability and provides a foundation for further development and operationalization.

We also contribute to the organizational and dynamic capabilities literature by empirically examining paradox management capability in the co-development context. While dynamic capabilities have previously been examined in the alliance context (e.g., Kale \& Singh, 2007; Zollo \& Winter, 2002), no previous study has integrated capability theorizing with paradox management in a relational context. The present study offers valuable conceptual and empirical insights into variations in paradox management capabilities and related managerial abilities in the selection of management approaches. The findings here indicate that companies employ multiple approaches for managing paradoxes, which they appear to select on the basis of their current business logic and past experiences. For example, while a company whose competitive advantage is based on technology and patents may be more interested in polarizing and focusing on knowledge protection in co-development, a company with negative experience of knowledge protection may be more eager to focus on knowledge sharing. This aligns with findings in the capability literature that history matters, and that changing their course of action is challenging for established firms (e.g., Schreyögg \& Kliesch-Eberl, 2007; Winter, 2003). Our study also shows that a company may deploy different management approaches for different paradoxes; for example, the industrial measurement system provider solved the governance paradox by fully polarizing on relational governance. However, to manage the paradox related to development goals, the same company relied on temporal separation to address customer-specific and general development goals in different phases of the development process. Furthermore, we also found that paradox management capabilities - when analyzed in organizational action - sometimes follow rather simple management approaches, while in other cases much more complex solutions are deployed. These differences reflect the ongoing discussion in the literature on the nature of dynamic capabilities that have been perceived both as "simple rules", as well as "complex routines" (for discussion, see e.g. Di Stefano et al., 2014; Schreyögg \& Kliesch-Eberl, 2007). For instance, some firms were shown to polarize strongly to contractual governance in all instances. This shows resemblance to the Eisenhardtian "simple rules" approach (Eisenhardt and Martin, 2000). On the other hand, some firms were shown to juxtapose different paradox elements simultaneously, following delicate and complex managerial approaches. These are reflections of a more "complex 
routines" approach. Overall, these results imply that paradox management capabilities can be viewed as firm-specific and idiosyncratic, as well as context- and history-dependent.

Finally, we add to the literature on the dark side of collaborative innovation. Recent studies have highlighted the tensions and paradoxes in inter-organizational relationships and networks associated with innovation (e.g., Fernandez et al., 2014; Laursen \& Salter, 2014; Ritala et al., 2017). Contributing to this discussion, we illustrate some negative phenomena that arise during collaboration in innovation with customers, such as the potential for opportunistic behavior (e.g., Noordhoff et al., 2011). For instance, there is evidence that collaboration and knowledge exchange may have negative implications, especially if they are not properly managed (Jiang et al., 2013; Ritala et al., 2015). In this regard, our findings of the paradox management capabilities of supplier firms indicate how to approach some of the difficulties arising from an "open" approach to codevelopment.

\subsection{Implications for managers}

We found evidence of many paradox management approaches that successfully polarize and juxtapose contradictory elements in co-development. We also found that companies had learned from past failures and developed better approaches for managing paradoxes, which suggests that paradox management capabilities develop over time as do other dynamic capabilities (see Zollo \& Winter, 2002). Some companies had adopted very simple managerial principles, while other companies had developed more delicate approaches to resolve some of the more contradictory challenges. Practicing managers can utilize these results in co-development projects by considering whether it is useful or possible to adopt solutions that polarize or juxtapose related to the identified paradoxes (relational and contractual governance, knowledge sharing and protection, customer-specific and general development goals). In this regard, some temporal and spatial solutions can be more readily applied than others, and we identified many examples of such decisions.

However, despite the importance of customer-driven innovation for all the participating companies, we also found that some did not consciously or systematically manage the inherent paradoxes of co-development. Our findings suggest that by making paradoxes more visible and choosing explicitly between polarizing and juxtaposing, firms can begin to develop this potentially important capability. For example, managers can adopt a more systematic approach to alternate over time between customer-specific and wider market needs. In the early phases of codevelopment, suppliers might focus on the needs of a particular customer, later developing these ideas into testable pilot solutions to see whether they serve a wider market need. For example in the development of new airplane engines, it is typical that the new prototypes are co-developed with the commercial airplane manufacturers to serve the needs of particular designs. However, as time passes, the new models will be tested also for wider market to cover the expensive development costs and to get full benefit of the new technology. This early customer-specific hypothesis generation - followed by later testing in wider markets - may be especially useful for firms in capital-intensive markets by helping to avoid lock-in to R\&D projects that do not serve wider needs. In general, we contend that paradox management (and associated capabilities) is company- and even relationship-specific, and that further investigation is needed to deepen understanding of this phenomenon. 


\subsection{Limitations and further research}

Like in any study, our research approach involves certain limitations. Although data were collected from multiple industries, the findings may be biased toward manufacturers of process technology, which were better represented. Only a few service providers were interviewed, which may limit generalization in this regard. Additionally, as the primary data were collected by interviewing only a few managers in each organization, the subjective perceptions of a single informant from one business unit may differ from those elsewhere in the firm, and wherever possible, secondary material was used to support the analysis. Furthermore, while it is quite common to study organizational actions as reflections of dynamic capabilities (see Laaksonen \& Peltoniemi, 2016), we acknowledge that by focusing merely on the "performative" aspects of capabilities has certain limitations. In particular, we did not provide evidence on longer-term causal mechanisms and financial and performance outcomes of applying different management approaches, nor did we track the consistency of their application over time.

All in all, our results can be seen as valuable but preliminary evidence, and further qualitative and quantitative research is needed to improve on the above-mentioned limitations. Our findings also open up interesting lines of inquiry into contingent factors affecting the selection of certain management approaches and the advantages and disadvantages of each. We believe that the introduction of paradox management capability opens several avenues for further research on managing collaboration between industrial suppliers and their customers. To begin, the construct of paradox management capability needs to be further developed if it is to be properly operationalized, measured and validated. After that, further studies should examine the link between paradox management capability and firm's financial and innovation performance, as well as relational performance in co-development relationships. Finally, future studies should focus in greater depth on the particular paradoxes identified here: knowledge sharing and protection, contractual and relational governance and customer-specific and generic goals. It would also be useful to further investigate the possible importance and implications of the co-development paradox of accelerating and delaying commercialization, as this preliminary finding did not emerge in our main study.

\section{References}

Aarikka-Stenroos, L., \& Jaakkola, E. (2012). Value co-creation in knowledge intensive business services: A dyadic perspective on the joint problem solving process. Industrial Marketing Management, 41, 15-26.

Aarikka-Stenroos, L., Sandberg, B., \& Lehtimäki, T. (2014). Networks for the commercialization of innovations: A review of how divergent network actors contribute. Industrial Marketing Management, 43, 365-381.

Adler, P.S., Goldoftas, B., \& Levine, D.I. (1999). Flexibility versus efficiency? A case study of model changeovers in the Toyota production system. Organization Science, 10, 43-68.

Andriopoulos, C., \& Lewis, M.W. (2009). Exploitation-exploration tensions and organizational ambidexterity: Managing paradoxes of innovation. Organization Science, 20, 696-717.

Bengtsson, M., \& Kock, S. (2000). "Coopetition" in business networks - To cooperate and compete simultaneously. Industrial Marketing Management, 29, 411-426.

Blazevic, V., \& Lievens, A. (2008). Managing innovation through customer coproduced knowledge in electronic services: An exploratory study. Journal of the Academy of Marketing Science, 36, 138-151. 
Biernacki, P., \& Waldorf, D. (1981). Snowball sampling: Problems and techniques of chain referral sampling. Sociological Methods \& Research, 10, 141-163.

Birkinshaw, J., Crilly, D., Bouquet, C., \& Lee, S. (2016). How do firms manage strategic dualities? A process perspective. Academy of Management Discoveries, 2, 51-78.

Blomqvist, K., Hurmelinna, P., \& Seppänen, R. (2005). Playing the collaboration game right Balancing trust and contracting. Technovation, 25, 497-504.

Bonner, J.M., \& Walker, O.C. (2004). Selecting influential business-to-business customers in new product development: Relational embeddedness and knowledge heterogeneity considerations. Journal of Product Innovation Management, 21, 155-169.

Campbell, A.J., \& Cooper, R.G. (1999). Do customer partnerships improve new product success rates?. Industrial Marketing Management, 28, 507-519.

Cantù, C., Corsaro, D., \& Snehota, I. (2012). Roles of actors in combining resources into complex solutions. Journal of Business Research, 65, 139-150.

Cao, Z., \& Lumineau, F. (2015). Revisiting the interplay between contractual and relational governance: A qualitative and meta-analytic investigation. Journal of Operations Management, 33-34, 15-42.

Carbonell, P., Rodriguez-Escudero, A.I., \& Pujari, D. (2012). Performance effects of involving lead users and close customers in new service development. Journal of Services Marketing, 26, 497-509.

Chang, W., \& Taylor, S.A. (2016). The effectiveness of customer participation in new product development: A meta-analysis. Journal of Marketing, 80, 47-64.

Coase, R.H. (1937). The nature of the firm. Economica, 4, 386-405.

Corsaro, D., Cantù, C., \& Tunisini, A. (2012). Actors' heterogeneity in innovation networks. Industrial Marketing Management, 41, 780-789.

Coviello, N.E., \& Joseph, R.M. (2012). Creating major innovations with customers: Insights from small and young technology firms. Journal of Marketing, 76, 87-104.

Day, G.S. (1994). The capabilities of market-driven organizations. Journal of Marketing, 58, 3752.

Davis, J.P., \& Eisenhardt, K.M. (2011). Rotating leadership and collaborative innovation recombination processes in symbiotic relationships. Administrative Science Quarterly, 56, 159-201.

Di Stefano, G., Peteraf, M., \& Verona, G. (2014). The organizational drivetrain: A road to integration of dynamic capabilities research. Academy of Management Perspectives, 28, 307-327.

Dubois, A., \& Gadde, L. E. (2002). Systematic combining: An abductive approach to case research. Journal of Business Research, 55, 553-560.

Eisenhardt, K.M., \& Martin, J.A. (2000). Dynamic capabilities: What are they?. Strategic Management Journal, 21, 1105-1121.

Fang, E., Lee, J., \& Yang, Z. (2015). The timing of codevelopment alliances in new product development processes: Returns for upstream and downstream partners. Journal of Marketing, 79, 64-82.

Fang, E. (2008). Customer participation and the trade-off between new product innovativeness and speed to market. Journal of Marketing, 72, 90-104.

Fang, E., Palmatier, R.W., \& Evans, K.R. (2008). Influence of customer participation on creating and sharing of new product value. Journal of the Academy of Marketing Science, 36, 322336. 
Feldman, M. S. (2003). A performative perspective on stability and change in organizational routines. Industrial and Corporate Change, 12, 727-752.

Feng, T., Sun, L., Zhu, C., \& Sohal, A.S. (2012). Customer orientation for decreasing time-tomarket of new products: IT implementation as a complementary asset. Industrial Marketing Management, 41, 929-939.

Fernandez, A.S., Le Roy, F., \& Gnyawali, D.R. (2014). Sources and management of tension in coopetition case evidence from telecommunications satellites manufacturing in Europe. Industrial Marketing Management, 43, 222-235.

Forkmann, S., Henneberg, S. C., Naudé, P., \& Mitrega, M. (2016). Supplier relationship management capability: A qualification and extension. Industrial Marketing Management, 57, 185-200.

Gaim, M., \& Wåhlin, N. (2016). In search of a creative space: A conceptual framework of synthesizing paradoxical tensions. Scandinavian Journal of Management, 32, 33-44.

Gioia, D. A., Corley, K.G., \& Hamilton, A.L. (2013). Seeking qualitative rigor in inductive research notes on the Gioia methodology. Organizational Research Methods, 16, 15-31.

Gnyawali, D.R., Madhavan, R., He, J., \& Bengtsson, M. (2016). The competition-cooperation paradox in inter-firm relationships: A conceptual framework. Industrial Marketing Management, 53, 7-18.

Helfat, C.E., \& Peteraf, M.A. (2015). Managerial cognitive capabilities and the microfoundations of dynamic capabilities. Strategic Management Journal, 36, 831-850.

Hobday, M. (2000). The project-based organization: An ideal form for managing complex product systems?. Research Policy, 29, 871-893.

Hooley, G.J., Möller, K., \& Broderick, A.J. (1998). Competitive positioning and the resource based view of the firm. Journal of Strategic Marketing, 6, 97-115.

Hooley, G., Saunders, J. and Piercy, N. (2004). Marketing Strategy and Competitive Positioning. Essex: Pearson Education Limited.

Hooley, G.J., Greenley, G.E, Cadogan, J.W. \& Fahy, J. (2005). The performance impact of marketing resources. Journal of Business Research, 58, 18-27.

Jiang, X., Li, M., Gao, S., Bao, Y., \& Jiang, F. (2013). Managing knowledge leakage in strategic alliances: The effects of trust and formal contracts. Industrial Marketing Management, 42, 983-991.

Johnsen, T.E. (2009). Supplier involvement in new product development and innovation: Taking stock and looking to the future. Journal of Purchasing and Supply Management, 15, 187197.

Johnston, W.J., \& Chandler, J.D. (2012). The organizational buying center: innovation, knowledge management and brand. In Lilien, G.L. \& Grewal, R. (Eds.), Handbook of Business-toBusiness Marketing, (pp. 582-95), Cheltenham, UK: Edward Elgar.

Järvenpää, S.L., \& Majchrzak, A. (2016). Interactive Self-Regulatory Theory for Sharing and Protecting in Interorganizational Collaborations. Academy of Management Review, 41, 9-27.

Kale, P., \& Singh, H. (2007). Building firm capabilities through learning: The role of the alliance learning process in alliance capability and firm-level alliance success. Strategic Management Journal, 28, 981-1000.

Knight, E., \& Harvey, W. (2015). Managing exploration and exploitation paradoxes in creative organizations. Management Decision, 53, 809-827. 
Laaksonen, O., \& Peltoniemi, M. (2016). The Essence of Dynamic Capabilities and their Measurement. International Journal of Management Reviews. Published online. DOI: 10.1111/ijmr.12122

Laursen, K., \& Salter, A.J. (2014). The paradox of openness: Appropriability, external search and collaboration. Research Policy, 43, 867-878.

Lewis, M.W. (2000). Exploring paradox: Toward a more comprehensive guide. Academy of Management Review, 25, 760-776.

Lewis, M.W., \& Smith, W.K. (2014). Paradox as a metatheoretical perspective sharpening the focus and widening the scope. The Journal of Applied Behavioral Science, 50, 127-149.

Lilien, G.L., Morrison, P.D., Searls, K., Sonnack, M., \& Hippel, E.V. (2002). Performance assessment of the lead user idea-generation process for new product development. Management Science, 48, 1042-1059.

Luzzini, D., Amann, M., Caniato, F., Essig, M., \& Ronchi, S. (2015). The path of innovation: Purchasing and supplier involvement into new product development. Industrial Marketing Management, 47, 109-120.

McGrath, J. (1982). Dilemmatics: The study of research choices and dilemmas. In J. McGrath, J. Martin \& R. Kulka, (Eds.), Judgment Calls in Research, (pp. 69-80), Beverly Hills, USA: Sage.

Mitrega, M., \& Pfajfar, G. (2015). Business relationship process management as company dynamic capability improving relationship portfolio. Industrial Marketing Management, 46, 193-203.

Mitrega, M., Forkmann, S., Ramos, C., \& Henneberg, S. C. (2012). Networking capability in business relationships - Concept and scale development. Industrial Marketing Management, 41, 739-751.

Möller, K. K., \& Halinen, A. (1999). Business relationships and networks: Managerial challenge of network era. Industrial Marketing Management, 28, 413-427.

Möller, K. (2006). Role of competences in creating customer value: A value-creation logic approach. Industrial Marketing Management, 35, 913-924.

Nambisan, S. (2002). Designing virtual customer environments for new product development: Toward a theory. Academy of Management Review, 27, 392-413.

Nijssen, E.J., Hillebrand, B., Jong, J.P., \& Kemp, R.G. (2012). Strategic value assessment and explorative learning opportunities with customers. Journal of Product Innovation Management, 29(S1), 91-102.

Nicolajsen, H.W., \& Scupola, A. (2011). Investigating issues and challenges for customer involvement in business services innovation. Journal of Business \& Industrial Marketing, 26, 368-376.

Noordhoff, C.S., Kyriakopoulos, K., Moorman, C., Pauwels, P., \& Dellaert, B.G. (2011). The bright side and dark side of embedded ties in business-to-business innovation. Journal of Marketing, 75, 34-52.

Olander, H., Hurmelinna-Laukkanen, P., Blomqvist, K., \& Ritala, P. (2010). The dynamics of relational and contractual governance mechanisms in knowledge sharing of collaborative R\&D projects. Knowledge and Process Management, 17, 188-204.

Patton, M.Q. (2015). Qualitative Research \& Evaluation Methods: Integrating Theory and Practice. 4th ed. California, USA: Sage.

Peled, M., \& Dvir, D. (2012). Towards a contingent approach of customer involvement in defence projects: An exploratory study. International Journal of Project Management, 30, 317-328. 
Pentland, B. T., \& Feldman, M. S. (2005). Organizational routines as a unit of analysis. Industrial and Corporate Change, 14, 793-815.

Poole, M.S., \& Van de Ven, A.H. (1989). Using paradox to build management and organization theories. Academy of Management Review, 14, 562-578.

Rindfleisch, A., \& Heide, J.B. (1997). Transaction cost analysis: Past, present, and future applications. Journal of Marketing, 61, 30-54.

Ritala, P., Hyötylä, M., Blomqvist, K., \& Kosonen, M. (2013). Key capabilities in knowledgeintensive service business. The Service Industries Journal, 33, 486-500.

Ritala, P., Olander, H., Michailova, S., \& Husted, K. (2015). Knowledge sharing, knowledge leaking and relative innovation performance: An empirical study. Technovation, 35, 22-31.

Ritala, P., Huizingh, E., Almpanopoulou, A., \& Wijbenga, P. (2017). Tensions in R\&D networks: Implications for knowledge search and integration. Technological Forecasting and Social Change, 120, 311-322.

Ritter, T., \& Geersbro, J. (2011). Organizational relationship termination competence: A conceptualization and an empirical test. Industrial Marketing Management, 40, 988-993.

Saunders, M., Lewis, P., \& Thornhill, A. (2009). Research Methods for Business Students. 5th ed. Harlow: FT/Prentice Hall.

Schreyögg, G., \& Kliesch-Eberl, M. (2007). How dynamic can organizational capabilities be? Towards a dual-process model of capability dynamization. Strategic Management Journal, 28, 913-933.

Smets, L.P., Langerak, F., \& Rijsdijk, S.A. (2013). Shouldn't customers control customized product development?. Journal of Product Innovation Management, 30, 1242-1253.

Smith, W. K. (2014). Dynamic decision making: A model of senior leaders managing strategic paradoxes. Academy of Management Journal, 57, 1592-1623.

Smith, W.K., \& Lewis, M.W. (2011). Toward a theory of paradox: A dynamic equilibrium model of organizing. Academy of Management Review, 36, 381-403.

Smith, W.K., \& Tushman, M.L. (2005). Managing strategic contradictions: A top management model for managing innovation streams. Organization Science, 16, 522-536.

Stanko, M.A., \& Bonner, J.M. (2013). Projective customer competence: Projecting future customer needs that drive innovation performance. Industrial Marketing Management, 42, 1255-1265.

Tavory, I., \& Timmermans, S. (2014). Abductive Analysis: Theorizing Qualitative Research. Chicago, USA: The University of Chicago Press.

Teece, D.J. (2007). Explicating dynamic capabilities: the nature and microfoundations of (sustainable) enterprise performance. Strategic Management Journal, 28, 1319-1350.

Teece, D.J. (2014). The foundations of enterprise performance: Dynamic and ordinary capabilities in an (economic) theory of firms. Academy of Management Perspectives, 28, 328-352.

Tidström, A. (2014). Managing tensions in coopetition. Industrial Marketing Management, 43, 261-271.

Tracey, P., Heide, J. B., \& Bell, S. J. (2014). Bringing “place” back in: Regional clusters, project governance, and new product outcomes. Journal of Marketing, 78, 1-16.

Tuli, K.R., Kohli, A.K., \& Bharadwaj, S.G. (2007). Rethinking customer solutions: From product bundles to relational processes. Journal of Marketing, 71, 1-17.

Ulaga, W., \& Reinartz, W.J. (2011). Hybrid offering: How manufacturing firms combine goods and services successfully. Journal of Marketing, 75, 5-23.

Ulwick, A.W. (2002). Turn customer input into innovation. Harvard Business Review, 80, 91-97. 
Winter, S.G. (2003). Understanding dynamic capabilities. Strategic Management Journal, 24, 991-995.

Yan, T., \& Dooley, K. (2014). Buyer-supplier collaboration quality in new product development projects. Journal of Supply Chain Management, 50, 59-83.

Zander, I., \& Zander, U. (2005). The inside track: On the important (but neglected) role of customers in the resource-based view of strategy and firm growth. Journal of Management Studies, 42, 1519-548.

Zollo, M., \& Winter, S.G. (2002). Deliberate learning and the evolution of dynamic capabilities. Organization Science, 13, 339-351. 